\title{
Lactic acid bacteria biodiversity in raw and fermented camel milk
}

\author{
*Akhmetsadykova S. ${ }^{1}$, Baubekova $A^{1}$, Konuspayeva $\mathbf{G}^{2,3}$, Akhmetsadykov $\mathbf{N}^{1}$, \\ Faye $B^{2,4}$, Loiseau $G^{5}$.
}

\author{
${ }^{1}$ Scientific and Production Enterprise Antigen Co. Ltd., 4 Azerbayev str., 040509, Almaty region, Kazakhstan \\ ${ }^{2}$ Conservation and Genetic Improvement Center, Camel project, P.O.Box 761, Al-Kharj, Kingdom of Saudi Arabia \\ ${ }^{3}$ Kazakh National al-Farabi University, Av. Al-Farabi, 050040, Almaty, Kazakhstan \\ ${ }^{4}$ UMR SELMET, CIRAD TA C-112A, Campus international de Baillarguet, 34398 Montpellier, France \\ ${ }^{5}$ UMR Qualisud, CIRAD, TA B-95/16, 73, rue J.-F. Breton, 34398 Montpellier Cedex 5, France \\ ${ }^{*}$ Corresponding author: shynar.akhmetsadykova@gmail.com, tel/fax: +77273890468
}

\begin{abstract}
Consumption of fermented camel milk, named shubat, is very popular in Central Asia and especially in Kazakhstan where it is known for its medicinal and dietary properties. To identify lactic acid bacteria (LAB) camel milk and shubat were sampled from 4 regions of Kazakhstan with important camel's population. In total, 26 dairy samples from 13 selected farms representing the variability of the farming system in the country were collected. Isolated strains were identified by genotypic approach including PCR using three different pairs of primers (338f/518r; W001/23S1; Lac1/Lac2/Lac3) and 16S rDNA gene sequencing. Three genus were in majority: Lactococcus, Lactobacillus and Enterococcus. The following microorganisms were identified: Enterococcus durans ; Enterococcus faecalis; Enterococcus faecium; Lactobacillus casei; Lactobacillus casei subsp. casei; Lactobacillus curvatus; Lactobacillus kefiri; Lactobacillus paracasei; Lactobacillus sakei; Lactococcus lactis subsp. lactis; Leuconostoc mesenteroides. Identification of camel milk and shubat microflora provides a theoretical foundation for developing starter cultures by using local LAB strains for industrial production of traditional fermented milk products.
\end{abstract}

Key words: camel milk, shubat, LAB, PCR, 16 S rDNA

\section{INTRODUCTION}

Camel milk and traditional fermented camel milk called shubat are valuable source of food for people living in steppe and arid areas of central Asia (Faye and Konuspayeva, 2012). These products are widely consumed in Kazakhstan and it is an important part of Kazakh people diet (Konuspayeva and Faye, 2011). Camel milk and shubat microflora plays major fermentative role in the aroma, texture and acidity; therapeutic role on improvement of digestion properties and responsible for antimicrobials properties (Arab et al. 2014).

Nowadays, interest for camel milk and shubat microflora is increasing. Different methods, like biochemical (Khelid et al. 2009) and 16S rDNA sequence analysis (Rahman et al. 2010; Wu et al. 2011) were used.
Methods based on the use of rRNA genes (rDNA) can analyze microflora on the basis of sequence diversity (Randazzo et al. 2002). By using this technique, it is easy to study and compare microbial communities in different feed like fermented dairy products. The most part of microflora diversity studies on different fermented products are established by using of PCR techniques (Van Hoorde et al. 2008; Vernile et al., 2008; Gaglio et al., 2014). Especially, using of PCR primers that target the 16S/23S rRNA (Berthier and Dusko-Ehrlich, 1998). This technique 16S rRNA gene sequencing was used for LAB identification in different dairy fermented products using different types of milk such yak, mare, goat, and cow milk (Yu et al., 2011; Bao et al., 2012).

Up to now, farmers are preparing shubat by using 
ancestral techniques, which are an important part of the tradition. The diversity in microflora composition of conventional starters originating from the respective family environment will result in shubat quality variability (Serikbayeva et al. 2005). Consequently, studying the microflora of traditional fermented dairy products as shubat is useful for organizing industrial production of traditional fermented products with local strains. It is one important step in development of camel milk processing (Yateem et al. 2008; Ashmaig et al. 2009)

After a preliminary identification of some of the microflora isolated from shubat samples reported elsewhere (Akhmetsadykova et al., 2014), the aim of the present paper was to study the microbiological biodiversity by providing the identification of the entire population of the spontaneous microflora in camel milk and shubat by using PCR-based methods and $16 \mathrm{~S}$ rDNA sequence analysis for the further starters' production.

\section{MATERIALS AND METHODS}

\section{Sampling procedure}

As the whole, 13 camel farms producing shubat by traditional way and representing the variability of the camel farming system were selected in four regions of the country: Almaty (one farm), South Kazakhstan (five farms), Kyzylorda (five farms) and Atyrau (two farms). Those regions were selected for their importance in camel stock. Selected farms reared the two species of large camelids (Camelus dromedarius and Camelus bactrianus) and their hybrids. In each farm, two samples were collected: fresh bulk milk and shubat prepared with the same milk. As the different species cohabited in the same farms, it was not possible to distinguish the milk according to the species. For each sample, has been assigned a code number according to region, farm and dairy sample type: Almaty (AL); South Kazakhstan (SK); Kyzylorda (KZ); Atyrau (AT); camel milk (M) and shubat (SH). For example, SKSH1 - shubat sample from the first farm situated in the South Kazakhstan region. Each sample $(n=26)$ was aseptically transferred to $500 \mathrm{ml}$ sterile bottle, transported in cold-box $\left(4^{\circ} \mathrm{C}\right)$ until Almaty, Kazakhstan, then frozen and transferred in France for identification analysis.

Identification steps

The identification process was achieved in the Qualisud laboratory, CIRAD, Montpellier, France. The different strains of lactic acid bacteria were identified by achieving a five-step analytical procedure described below:

\section{Step 1: Isolation and growth conditions}

$L A B$ strains were isolated from sample by using wire loops on the M17 and MRS agar (Biokar Diagnostics,
France). After the incubation period $\left(48 \mathrm{~h}, 37^{\circ} \mathrm{C}\right)$, single colonies that had different morphological traits were subcultured. Cells were maintained at $-20^{\circ} \mathrm{C}$ in the culture broth supplemented with $30 \%$ glycerol.

\section{Step 2: Preliminary identification}

The strains were characterized by Gram's staining (reagent kit "Color Gram2-E" BioMérieux, France), catalase tests (ID color catalase ID-ASE Biomérieux, France) and oxidase tests (Oxidase reagent Biomérieux, France).

\section{Step 3: DNA extraction and storage}

Bacterial DNA extraction was achieved according to the manual method described by Leesing (2005). The extracted DNA was stored at $-20^{\circ} \mathrm{C}$. Existence and purity of DNA was verified by electrophoresis in $0.8 \%(\mathrm{w} / \mathrm{v})$ agarose gel (Promega, France) in TAE 1X buffer under UV light after ethidium bromide staining.

\section{Step 4: Amplification of DNA by PCR}

Each DNA sample was amplified 3 times by using different pairs of primers:

primers 338f (5'-ACTCCTACGGGAGGCAGCAG-3') and 518r (5'-ATT ACC GCG GCT GCT GG-3') (SigmaGenosys, France) (Leesing, 2005);

primers W001 (5'- AGA GTT TGA TCM TGG CTC-3') and $23 \mathrm{~S} 1$ (5'- CNC GTC CTT CAT CGC CT-3') (SigmaGenosys, France) (Turpin et al., 2011);

primers Lac1 (5'-AGCAGTAGGGAATCTTCCA-3') or Lac3 (5'-AGCAGTAGGGAATCTTCCA-3') and reverse primer Lac2 GC

(5'CGCCCGGGGCGCGCCCCGGGCGGCCCGGGGGC ACCGGGGGATTYCACCGCTACACATG-3') (SigmaGenosys, France) (Santos et al., 2011).

\section{Step 5: Purification and Sequencing of PCR bands}

Agarose gel electrophoresis was performed to visualize amplified DNA fragments and to excise corresponded bands with sterile scalpel under UV light after ethidium bromide staining. The amplicons of PCR were purified with Wizard PCR Preps DNA Purification system kit (Promega, France) and stored at $-20^{\circ} \mathrm{C}$. Sequencing was done by Eurofins Genomics enterprise. Sequence annotation and database searches for similar sequences were performed by using BLAST at the National Center for Biotechnology Information (http://www.ncbi.nlm.nih.gov/) to determine the closest known relative species.

\section{RESULTS AND DISCUSSION}

In total, 130 strains were isolated from 26 dairy samples. 
86 Afr. J. Food Sci. Technol.

Table 1. Phylogenetic affiliations of 48 LAB strains isolated from raw camel milk and shubat from four regions of Kazakhstan.

\begin{tabular}{|c|c|c|c|c|c|c|}
\hline \multirow{2}{*}{$\begin{array}{l}\text { Strain's } \\
\text { origin }\end{array}$} & \multirow{2}{*}{ Species } & \multirow{2}{*}{$\begin{array}{l}\text { DNA sequence } \\
\text { identity } 165 \\
\text { rDNA gene (\%) }\end{array}$} & \multicolumn{4}{|c|}{ Specificity of PCR primers } \\
\hline & & & $338 f / 518 r$ & W001/23S1 & $\begin{array}{l}\text { Lac1, } \\
\text { Lac3 }\end{array}$ & Lac2, \\
\hline SKM1 & Leuconostoc mesenteroides & 92 & - & + & - & \\
\hline SKM3 & Leuconostoc mesenteroides & 100 & + & + & - & \\
\hline SKSH1 & Leuconostoc mesenteroides & 97 & + & - & - & \\
\hline SKM2 & Leuconostoc mesenteroides & 98 & + & + & - & \\
\hline SKSH2 & Enterococcus durans & 99 & + & + & + & \\
\hline SKSH1 & Enterococcus durans & 98 & + & + & - & \\
\hline SKSH2 & Enterococcus durans & 99 & + & - & - & \\
\hline $\mathrm{KZSH} 2$ & Enterococcus durans & 95 & + & + & - & \\
\hline SKSH5 & Enterococcus durans & 98 & + & + & + & \\
\hline SKSH1 & Enterococcus durans & 95 & + & - & - & \\
\hline SKSH2 & Enterococcus durans & 97 & + & - & - & \\
\hline $\mathrm{KZSH} 2$ & Enterococcus durans & 88 & - & + & - & \\
\hline SKM5 & Enterococcus durans & 99 & + & - & - & \\
\hline SKM1 & Enterococcus durans & 99 & + & + & + & \\
\hline SKSH3 & Enterococcus durans & 98 & - & + & + & \\
\hline SKSH5 & Enterococcus durans & 98 & + & + & - & \\
\hline SKSH5 & Enterococcus durans & 98 & - & + & - & \\
\hline $\mathrm{KZSH} 2$ & Enterococcus faecalis & 92 & + & + & - & \\
\hline SKSH1 & Enterococcus faecalis & 99 & + & + & - & \\
\hline SKSH1 & Enterococcus faecalis & 100 & + & + & - & \\
\hline ATSH1 & Enterococcus faecalis & 99 & + & + & - & \\
\hline SKM4 & Enterococcus faecalis & 100 & + & + & - & \\
\hline ALSH1 & Enterococcus faecium & 90 & + & + & + & \\
\hline ATSH3 & Enterococcus faecium & 99 & + & + & - & \\
\hline SKSH5 & Enterococcus faecium & 99 & + & + & - & \\
\hline ATM2 & Enterococcus faecium & 98 & + & + & - & \\
\hline SKSH2 & Enterococcus faecium & 99 & + & + & - & \\
\hline SKSH4 & Enterococcus faecium & 99 & + & + & - & \\
\hline SKM2 & Enterococcus faecium & 99 & + & + & - & \\
\hline SKM3 & Enterococcus faecium & 99 & + & + & + & \\
\hline KZM5 & Enterococcus faecium & 99 & + & - & - & \\
\hline KZM5 & Enterococcus faecium & 98 & + & + & - & \\
\hline KZSH1 & Enterococcus faecium & 81 & + & - & - & \\
\hline SKM2 & Enterococcus faecium & 99 & + & - & - & \\
\hline $\mathrm{KZSH} 2$ & Enterococcus faecium & 98 & + & + & - & \\
\hline SKSH1 & Lactobacillus kefiri & 99 & + & - & + & \\
\hline SKM2 & Lactobacillus bucheri & 93 & + & + & - & \\
\hline $\mathrm{KZSH} 2$ & Lactobacillus casei & 99 & + & + & - & \\
\hline ALSH1 & Lactobacillus casei & 100 & + & + & - & \\
\hline $\mathrm{KZSH} 2$ & Lactobacillus casei & 99 & + & - & - & \\
\hline KZM5 & Lactobacillus casei subsp. casei & 98 & + & + & - & \\
\hline SKSH4 & Lactobacillus casei subsp. casei & 99 & + & + & - & \\
\hline SKSH1 & Lactobacillus sakei & 100 & + & + & - & \\
\hline KZM4 & Lactobacillus sakei & 100 & + & + & - & \\
\hline SKSH1 & Lactobacillus sakei & 95 & + & + & - & \\
\hline SKM3 & Lactobacillus sakei & 100 & + & + & - & \\
\hline $\mathrm{KZSH} 2$ & Lactococcus lactis subsp. lactis & 99 & + & - & - & \\
\hline SKM3 & Lactococcus lactis subsp. lactis & 100 & + & + & - & \\
\hline
\end{tabular}

All these strains were tested by Gram's staining, oxidase and catalase tests. After laboratory screening, 118 strains were Gram positives, oxidase and catalase negative and non-spore forming bacteria which were considered as lactic acid bacteria strains. The majority of isolates were cocci (70\%).
All 118 LAB strains were taken for molecular identification analysis. PCR amplification results showed existence of microorganisms (26) which could not be identified by used primers.

From 118 strains, 44 were identified only until genera: Lactococcus (18); Lactobacillus (14); Leuconostocs (7) 
and Enterococcus (5). Other 48 strains were identified until species. Most of them were identified by using primers 338f/518r and W001/23S1. In contrast, the primers Lac1, Lac2, Lac3 failed to produce an amplicons in all tested strains, except 7 strains (Table 1).

The percentage of similarity for $48 \mathrm{LAB}$ strains with their affiliations showed high identity $81 \%-100 \%$. The rDNA sequences demonstrated similarity with $16 \mathrm{~S}$ rDNA sequences of members of the Enterococcus, Lactobacillus, Lactococcus, Leuconostoc genera in GenBank.

Results cannot give full information about diversity of $L A B$ in these products and about microflora diversity per region. However, it supplies some idea about microflora of camel milk and shubat from Kazakhstan which was not investigated deeply yet. The identification was achieved on mixed milk in farms with heterogeneous camel population; it was not possible to present results by species and to determine a potential specific difference. According to research results, Enterococcus and Lactococcus genus seem to be dominating in camel milk and shubat. Similar results on preponderant cocci microorganisms of camel milk compared to other species' milk have been already reported in the literature (Dalmasso et al; 2008; Ashmaig et al., 2009; Khedid et al., 2009; Rahman et al., 2010). This is opposite to mare's milk and koumiss microflora where bacilli, especially Lactobacillus strains are dominant (Wang et al., 2008; Hao et al., 2010; Sun et al., 2010). In Ititu, a traditional Ethiopian fermented camel milk, Seifu et al. (2012) found $58 \%$ Lactobacillus, 25\% Lactococcus and $17 \%$ Enterococcus, but the identification of their 146 strains was based on biochemical tests only. In shubat collected from 7 Bactrian samples in China, Rahman et al. (2009), using biochemical test (API $50 \mathrm{CHL}$ ) and molecular method (16s rDNA gene sequencing PCR amplification and by using $\mathrm{pA}$ and $\mathrm{pH}$ primers), identified 48 LAB isolates where Lactobacillus end Enterococcus were predominant.

In our study, 26 isolates could not be identified with the used primers. To study these not identified strains and research microbiological richness of these traditional dairy products other more appropriate primers should be found or be designed (Schleifer et al., 1995; Heilig et al., 2002; Odamaki et al., 2011). It is admitted that accurate identification of Lactobacillus species can be accomplished by reference to $16 S$ rRNA gene sequences. However, species-specific, PCR primers that target the 16S-23S rRNA spacer region are available for a limited number of Lactobacillus species (Tannock, 1999).

In the present study, one of the dominating genus Enterococcus group was presented by 3 different species such E. faecium, E. durans and E. faecalis. The predominance of enterococci, especially Enterococcus faecalis, in camel milk microflora was also reported by Benkerroum, et al. (2003) in Morocco, and by Jans et al.
(2012) in Kenya. But, for many authors, presence of enterococci is evidence of possible fecal contamination and therefore a risk to consumers because although these strains are known for their low virulence, they could pose serious health problems especially because the emergence of antibiotic-resistant strains, for example strains of E. faecalis (Khedid et al. 2009). However, the positive role of these cocci in the development of quality of fermented dairy products should not be forgotten. Indeed, the proteolytic properties of these strains lead to the release of casein amino acid precursors of molecules involved in the flavor of cheese (Khedid et al. 2009; ZadiKaram and Karam, 2011). Also, a specific inhibitory activity of enterococci was showed against some pathogenic bacteria (Sabia et al. 2002).

However, the difference between species milk microflora diversity could be due to geographical, environmental and milk composition (Aziz et al. 2009).

\section{CONCLUSION}

This study emphasized the high biodiversity of microflora available in fermented camel milk in Kazakhstan. The identification of the remaining isolated LAB strains should be done to give a definitive idea of microflora diversity in this product. Moreover, the link between microflora population and variation factors as species or regions could be investigated to understand the variability in organoleptic properties of the different shubat samples. And the further studies will be very important step in creation of starters and probiotics based on local lactic acid bacteria strains as it is expected through the commercialization project "Starters for manufacturers of national fermented milk products" in Kazakhstan.

\section{REFERENCES}

Akhmetsadykova Sh, Baubekova A, Konuspayeva G, Akhmetsadykov $\mathrm{N}$, Loiseau $\mathrm{G}$ (2014). Microflora identification of fresh and fermented camel milk from Kazakhstan. Emir. J. Food Agric., 16(4): 327-332

Arab HH, Salama SA, Eid AH, Omar HA, El-Shaimaa AA, Maghrabi IA (2014). Camel's milk ameliorates TNBS-induced colitis in rats via down-regulation of inflammatory cytokines and oxidative stress. Food Chem. Toxicol., 69: 294-302.

Ashmaig A, Hasan A, El Gaali E (2009). Identification of lactic acid bacteria isolated from traditional Sudanese fermented camel's milk (Gariss). African J. Microbiol Res., 38: 451-457.

Aziz T, Khan H, Bakhtair SM, Naurin M (2009). Incidence and relative abundance of lactic acid bacteria in raw milk of buffalo cow and sheep. J. Anim. Plant Sci. 19, 4: 168-173

Bao Q, Yu J, Liu W, Qing M, Wang W, Chen X, Wang F, Li M, Wang H, Zhang QLH (2012). Predominant lactic acid bacteria in traditional fermented yak milk products in the Sichuan Province of China. Dairy Sci. Technol. 92, 3: 309-319

Benkerroum N, Boughdadi A, Bennani N, Hidane K (2003). Microbiological quality assessment of Moroccan camel's milk and identification of predominating lactic acid bacteria World $\mathrm{J}$. Microbiol. Biotechnol., 19 (6): 645-648

Berthier F, Dusko Ehrlich S (1998). Rapid species identification within two groups of closely related lactobacilli using PCR primers that 
88 Afr. J. Food Sci. Technol.

target the 16S/23S rRNA spacer region FEMS. Microbiol. Letters, 161: $97-106$

Dalmasso M, Prestoz S, Rigobello V, Demarigny Y (2008). Evolution of the raw cow milk microflora especially lactococci enterococci leuconostocs and lactobacilli over a successive 12 day milking regime. Int. J. Dairy Sci. 3: 117-130

Faye B, Konuspayeva G (2012). The sustainability challenge of the dairy sector- The growing importance of the non-cattle milk production worldwide. Int. Dairy J. 24: 50-56

Gaglio R, Francesca N, Di Gerlando R, Cruciata M, Guarcello R, Portolano B, Moschetti G, Settanni L (2014). Identification typing and investigation of the dairy characteristics of lactic acid bacteria isolated from "Vastedda della valle del Belice" cheeses. Dairy Sci. Technol. 94, 2: 157-180

Hao Y, Zhao L, Zhang H, Zhai Z, Huang Y, Liu X, Zhang L (2010). Identification of the bacterial biodiversity in koumiss by denaturing gradient gel electrophoresis and species-specific polymerase chain reaction. J. Dairy Sci. 93: 1926-1933

Heilig HG, Zoetendal EG, Vaughan EE, Marteau P, Akkermans AD, de Vos WM (2002). Molecular diversity of Lactobacillus spp and other lactic acid bacteria in the human intestine as determined by specific amplification of $16 \mathrm{~S}$ ribosomal DNA Applied Environ. Microbiol. 68(1): 114-23

Jans C, Bugnard J, Njage PMK, Lacroix C, Meile L (2012). Lactic acid bacteria diversity of African raw and fermented camel milk products reveals a highly competitive potentially health-threatening predominant microflora. Food Sci. Technol. 47: 371-379

Khedid K, Faid M, Mokhtari A, Soulaymani A, Zinedine A (2009). Characterization of lactic acid bacteria isolated from the one humped camel milk produced in Morocco Microbiol. Res. 164(1): 81-91

Konuspayeva G, Jurjanz S, Loiseau G, Barci V, Akhmetsadykova S, Meldebekova A, Faye B (2011). Contamination of camel milk (heavy metals organic pollutants and radionuclides). in Kazakhstan. J. Environnem. Protect. 2: 90-96

Leesing R (2005). Identification et validation de marqueurs spécifiques pour la traçabilité des poissons d'aquacultures lors de leur import/export PhD thesis University Montpellier II Montpellier France Retrieved insert the date from 20 November 2013 http://wwwthesesfr/2005MON20150

Mal G, Sena DS, Jain VK, Sahani MS (2006). Therapeutic value of camel milk as a nutritional supplement for multiple drug resistant (MDR). tuberculosis patients Israel J Vet. Medicine. 61: 88-91

Odamaki T, Yonezawa S, KitaharaM, Sugahara Y, Xiao JZ, Yaeshima T, Iwatsuki K, Ohkuma M (2011). Novel multiplex polymerase chain reaction primer set for identification of Lactococcus species. Letter Appl. Microbiol. 52(5): 491-496

Rahman N, Chen X-h, Dong MS (2010). PCR-DGGE Analysis of microbial community in shubat from Xinjiang. Food Sci. 31(11): 136140

Rahman N, Xiaohong C, Meiqin F, Mingsheng D (2009). Characterization of the dominant microflora in naturally fermented camel milk shubat. World J. Microbiol. Biotechnol. 25: 1941-1946

Randazzo CL, Torriani S, Akkermans ADL, de Vos WM, Vaughan EE (2002). Diversity dynamics and activity of bacterial communities during production of an artisanal sicilian cheese as evaluated by 16S rRNA analysis. Appli Environ. Microbiol. 1882-1892

Sabia C, Manicarda G, Messai ,P De Niederhānsern S, Bondi M (2002). Enterocin $416 \quad \mathrm{~K} 1$ an antilisterial bacteriocin produced by Enterococcus casseliflavus IM $416 \mathrm{~K} 1$ isolated from Italian sausages. Int J. Food Microbiol., 75: 163-170
Santos TF, Santana LKA, Santos ACF, Silva GS, Romano CC, Dias JCT, Rezende RP (2011). Lactic acid bacteria dynamics during spontaneous fermentation of cocoa beans verified by cultureindependent denaturing gradient gel electrophoresis. Genet. Molecul. Res. 10(4): 2702-2709

Schleifer KH, Ehrmann M, Beimfohr C, Brockmann E, Ludwig W, Amann R (1995). Application of molecular methods for the classification and identification of lactic acid bacteria. Int. Dairy J. 5(8): 1081-1094

Seifu E, Abraham A, Kurtu MV, Yilma Z (2012). Isolation and characterization of lactic bacteria from Itiltu: Ethiopian traditional fermented camel milk. J Camelid Sci. 5: 92-98

Serikbayeva A, Konuspayeva G, Faye B, Loiseau G, Narmuratova M (2005). Probiotic properties of a sour-milk shubat from the camel milk. In: "Desertification Combat and Food Safety In Faye B Esenov $P$ (Eds). The Added Value of Camel producers ( $p p$ 187-191). Ashkabad (Turkmenistan). NATO Sci Series Life and Behavioural Scis Vol 362 IOS Press Amsterdam (Pays-Bas).

Sun Z, Liu W, Zhang J, Yu J, Zhang W, Cai C, Menghe B, Sun T, Zhang $H$ (2010). Identification and characterization of the dominant lactobacilli isolated from koumiss in China. J. Gener. Appl. Microbiol. 56(3): 257-65

Tannock GW (1999). Identification of Lactobacilli and Bifidobacteria Current Issues Molecul. Biol. 1(1): 53-64

Turpin W, Humblot C, Guyot JP (2011). Genetic screening of functional properties of lactic acid bacteria in fermented pearlmillet slurry and in the metagenome of fermented starchy foods. Appl.Environ. Microbiol., 77: 8722-8734

Van Hoorde K, Vandamme P, Huys G (2008). Molecular identification and typing of lactic acid bacteria associated with the production of two artisanal raw milk cheeses. Dairy Sci. Technol. 88(4-5): 445-455

Vernile A, Giammanco G, Spano G, Beresford TP, Fox PF, Massa S (2008). Genotypic characterization of lactic acid bacteria isolated from traditional Pecorino Siciliano cheese. Dairy Sci. Technol. 88(6): 619-629

Wang J, Chen X, Liu W, Yang M, Airidengcaicike, Zhang H (2008). Identification of Lactobacillus from koumiss by conventional and molecular methods. European Food Res. Technol. 227(5): 15551561

Wu Y, Huang P, Li Y, Zhang XY, Xu ZZ, Wang BF, Shi J (2011). Molecular Biological Identification of Lactic Acid Bacteria in Fermented Camel Milk as a Kazakh Traditional Food in Xinjiang. Food Sci. 32(1): 173-176

Yateem A, Balba MT, Al-Surrayai T, Al-Mutairi B, Al-Daher R (2008). Isolation of lactic acid bacteria with probiotic potential from camel milk. Int. J. Dairy Sci 3(4): 194-199

Yu J, Wang WH, Menghe BLG, Jiri MT, Wang HM, Liu WJ, Bao QH, Lu Q, Zhang JC, Wang F, Xu HY, Sun TS, Zhang HP (2011). Diversity of lactic acid bacteria associated with traditional fermented dairy products in Mongolia. J. Dairy Sci. 94 : 3229-3241

Zadi-Karam H, Karam NE (2005). Bactéries lactiques du lait de chamelle. Renc. Rech. Ruminants $12: 399$ 